\title{
Behavioral variant frontotemporal dementia in patients with previous severe mental illness: a systematic and critical review
}

\author{
Demência frontotemporal variante comportamental em pacientes com transtorno mental \\ grave prévio: revisão sistemática e crítica \\ Leandro Boson GAMBOGI1,2, Henrique Cerqueira GUIMARÃES ${ }^{1,2}$, Leonardo Cruz DE SOUZA ${ }^{1,2}$, Paulo CARAMELLI1,2
}

\begin{abstract}
Objectives: To explore the relationship between severe/serious mental illness (SMI) and the behavioral variant of frontotemporal dementia (bvFTD), as the patterns of symptoms and cognitive performance that characterize both disorders share similarities. Methods: We performed a systematic review investigating what has already been published regarding the relationship between bvFTD and SMI. Studies were selected from PubMed and LILACS databases, including those published up to February 12, 2018. The search strategy included the following terms: "frontotemporal dementia" plus "bipolar", OR "frontotemporal dementia" plus "schizophrenia", OR "frontotemporal dementia" plus "schizoaffective". Publications without abstracts, case reports with absent genetic or histopathological confirmation, reviews and non-English language papers were excluded across the search process. Results: The search on PubMed retrieved 186 articles, of which 42 met eligibility criteria. On the LILACS database, none met the requirements. Generally, three major research aims were identified: 1) to look for frontotemporal lobar degeneration-associated genetic abnormalities in patients with prior SMI; 2) to compare the cognitive profile between patients affected by neurodegenerative disorders and schizophrenic patients; 3) to highlight the association between bvFTD and preceding psychiatric conditions and/or distinguish them both. The investigated mutations were found infrequently in the studied SMI samples. Cross-sectional studies comparing cognitive performance between bvFTD and psychiatric disorders mostly found no remarkable differences. There were only a few case reports identifying definite frontotemporal lobar degeneration in patients with previous psychiatric diagnoses. Conclusions: The available evidence demonstrates how fragile the current understanding is regarding the association between bvFTD and prior SMI.
\end{abstract}

Keywords: Bipolar disorder; frontotemporal dementia; psychotic disorders; schizophrenia.

\section{RESUMO}

Objetivos: Explorar a relação entre doença mental grave (DMG) e a variante comportamental da demência frontotemporal (DFTvc), uma vez que os padrões de sintomas e de desempenho cognitivo que caracterizam ambos os transtornos compartilham semelhanças. Métodos: Revisão sistemática investigando estudos publicados sobre a relação entre DFTvc e DMG. Os estudos foram selecionados nas bases de dados PubMed e LILACS, incluindo aqueles publicados até 12 de fevereiro de 2018. A estratégia de busca incluiu os seguintes termos: "demência frontotemporal" "bipolar", OU "demência frontotemporal" e "esquizofrenia" OU “demência frontotemporal" "esquizoafetivo". Publicações sem resumos, relatos de casos sem confirmação genética ou histopatológica, revisões e artigos escritos em idiomas que não fossem o inglês não foram selecionados na busca sistemática. Resultados: A pesquisa no PubMed encontrou 186 artigos, dos quais 42 alcançaram critérios de elegibilidade. Na base de dados LILACS, nenhum dos nove artigos identificados atendeu aos requisitos. Foram identificados três objetivos de pesquisa principais: buscar anormalidades genéticas associadas à degeneração lobar frontotemporal (DLFT) em pacientes com SMI prévia; comparar o perfil cognitivo entre pacientes acometidos por doenças neurodegenerativos e esquizofrênicos; destacar a associação entre DFTvc e condições psiquiátricas precedentes e/ou distinguir ambos. As mutações investigadas foram encontradas infrequentemente nas amostras estudadas. Os estudos transversais comparando o desempenho cognitivo entre DFTvc e os transtornos psiquiátricos não encontraram diferença, e houve apenas relatos de casos confirmando de DLFT em pacientes com diagnósticos psiquiátricos prévios. Conclusões: A evidência disponivel demonstra quão frágil é o entendimento atual sobre a associação entre DFTvc e DMG.

Palavras-chave: Transtorno bipolar; demência frontotemporal; transtornos psicóticos; esquizofrenia.

\footnotetext{
'Universidade Federal de Minas Gerais, Faculdade de Medicina, Departamento de Clínica Médica, Grupo de Pesquisa em Neurologia Cognitiva e do Comportamento Belo Horizonte MG, Brasil;

Universidade Federal de Minas Gerais, Programa de Pós-Graduação em Neurociências, Belo Horizonte MG, Brasil.

Leandro Boson Gambogi (iD https://orcid.org/0000-0002-1268-8872; Henrique Cerqueira Guimarães (iD) https://orcid.org/0000-0002-6680-7099; Leonardo Cruz de Souza (iD) https://orcid.org/0000-0001-5027-9722; Paulo Caramelli (iD) https://orcid.org/0000-0002-4786-6990

Correspondence: Paulo Caramelli; Departamento de Clínica Médica - Faculdade de Medicina da UFMG; Avenida Alfredo Balena, 190 / Sala 246; 30130-100 Belo Horizonte MG, Brasil; E-mail: caramelli@ufmg.br

Conflict of interest: There is no conflict of interest to declare.
}

Received 26 November 2018; Received in final form 05 May 2019; Accepted 11 May 2019. 
Although mortality is higher and life expectancy is far shorter in people with severe/serious mental illness (SMI), recent epidemiological studies have suggested that this group of individuals is also affected, albeit to a minor extent, by the same demographic changes that have driven population aging worldwide ${ }^{1}$. According to epidemiological research in other populations, it is reasonable to conceive that in these individuals with SMI, who are usually exposed to an unhealthy lifestyle, cognitive decline and overt dementia in the long run are probable outcomes if they reach old age. The relationship between severe psychiatric disorders and dementia has been recognized remotely, such as Kraepelin's description of "dementia praecox". Additionally, nowadays it is undisputed that psychiatric symptoms, such as mood changes, delusions, hallucinations, anxiety and others, constitute an essential hallmark of dementia.

The diagnosis of dementia in a person with a lifetime severe psychiatric disorder, such as severe relapsing unipolar depression, bipolar affective disorder (BD), and schizophrenia (SCZ) spectrum disorders is a challenging task. Most major neurocognitive disorders diagnostic proposals state that the patients' deficits "should not be better explained" by a psychiatric condition. In fact, there is a general tendency to attribute to a basal disorder, either neurological or psychiatric, novel symptoms or signs allegedly arising from brain malfunction.

Unfortunately, however, there are few reports that have systematically evaluated the issue of dementia superimposing lifetime psychiatric disorders. It is unclear whether the dementia symptoms observed in these patients represent a new condition, such as Alzheimer's disease $(\mathrm{AD})$, but with phenotypic clinical features modified by the premorbid disorder; or whether in some individuals the observed cognitive decline should be regarded as a natural stage of the psychiatric disorder itself.

To accomplish this purpose, large cohorts of psychiatric patients should be followed for decades, with their cognitive and functional performance under objective evaluation, preferably with detailed longitudinal structural neuroimaging analyses and, critically, under a diagnostic framework that should recognize the presence of significant cognitive and functional decline as a dementia equivalent. To the best of our knowledge, a research project like this has not been conducted so far.

Meanwhile, the identification of genetic mutationsmicrotubule-associated protein tau gene (MAPT), progranulin gene $(G R N)$, and chromosome 9 open reading frame 72 (C9orf72) gene, responsible for up to $15 \%$ of the frontotemporal lobar degeneration (FTLD) group of disorders ${ }^{2}$ - provide a framework to investigate cross-sectionally the prevalence of a neurodegenerative disease in this select group of patients. The advent of biomarkers related to $\mathrm{AD}$ in the cerebrospinal fluid (CSF) and positron emission tomography (PET) scans with beta-amyloid or tau tracers also allow a better investigation of neurodegenerative pathological substrates in this group of individuals with SMI.

Severe/serious mental illness is a clinical concept generally established by its duration and by the functional decline that it produces, encompassing disorders that cause psychotic symptoms, such as SCZ and schizoaffective disorder (SZA), and severe/psychotic presentations of affective disorders, such as severe major depression and $\mathrm{BD}^{3}$. This concept is also replicated by the National Institute of Mental Health, which defines SMI as a mental, behavioral, or emotional disorder (excluding developmental and substance use disorders) of sufficient duration to meet diagnostic criteria specified within the Diagnostic and Statistical Manual of Mental Disorders (DSM), and resulting in serious functional impairment that substantially interferes with or limits one or more major life activities.

Bipolar affective disorder, SZA and SCZ, especially, may be grouped together as SMIs, not only by their severity, but also because they might be indistinguishable from a biological perspective ${ }^{4}$. Clementz et al. $^{4}$, based on multivariate analyses from cognitive, electroencephalographic, and oculomotor paradigms, identified three neurobiologically distinct psychosis biotypes previously classified within the psychosis dimension, and documented that each biotype included all DSM psychosis categories. The same three biotype constructs were later the objects of a study that examined whole brain gray matter density measures in probands, their relatives, and healthy individuals, organized by their biotype, and then by DSM diagnoses. The research pointed to brain anatomy characteristics, measured by reduced gray matter density, consistent with their cognitive and sensorimotor profile first described ${ }^{5}$. The biotype 1 included individuals with a mean age of 35.3 years and mean age of illness onset of 20.5 years. The participants presented with severely impaired cognition and sensorimotor function, and had extensive and diffuse gray matter loss, more apparent in the frontal, anterior/middle cingulate cortex, and temporal regions. Pooroutcome individuals made up this group. The biotype 2 was typified by moderately impaired cognition and accentuated sensorimotor reactivity, with intermediate and more localized gray matter atrophy, more obvious in insula and frontotemporal regions. The mean age of the group was 35.4 years and mean age of onset of illness was 20.8 years; biotype 3, which had a mean age of 35.3 years and mean onset of illness at 20.3 years, presented with near-normal cognition and close to normal sensorimotor function, with small reductions in anterior limbic regions. Therefore, distinguishing an ongoing dementia process would be especially challenging for the most severely impaired groups, which already have brain anatomy abnormalities ${ }^{5}$.

The diagnostic challenge of recognizing dementia in a patient with lifetime severe psychiatric disorder is far more puzzling when considering the possibility of behavioral variant frontotemporal dementia (bvFTD), in which many 
patients do not routinely show gross cognitive deficits, particularly in their early stages. Several reports have documented that a large number of patients with bvFTD are, indeed, initially labeled with classical psychiatric conditions ${ }^{6,7}$.

To consider the relationship between SMI and bvFTD, we performed a systematic review investigating the available data regarding the interface between these conditions. First, we provide a very brief overview on the recent history of bvFTD and its neurobiological underpinnings, introducing the overlapping features between this type of dementia and primary psychiatric symptoms. Then we present the systematic review itself and discuss the available findings. Lastly, we present a critical analysis and propose a script to understand current evidence, which may be useful for future studies in the field.

\section{FRONTOTEMPORAL DEMENTIA OVERVIEW}

The predominant degeneration of the frontal and temporal cortex, first described in 1892 by Arnold Pick, usually induces a clinical presentation characterized by progressive behavioral and personality changes, and/or language impairment. Despite this long-standing description, formal diagnostic criteria and classification of clinical subtypes were first proposed only about 20 years ago and have been a subject of intense modification since then. Initially developed by a consensus of researchers in 1994, the criteria were subsequently refined by an international consensus in 1998 to include presentations with predominant language involvement. At that time, the term FTLD was proposed to define a group of a few pathological conditions associated with a broad spectrum of syndromes with overlapping clinical presentations, ranging from those with predominant behavioral changes to progressive language impairment. More recently, the clinical criteria for bvFTD diagnosis have been revised ${ }^{8}$, substantially raising its sensitivity, albeit with a compromised specificity when used to tell it apart from FTLD and psychiatric disorders $^{9}$. Concurrently, the criteria for clinical characterization of primary progressive aphasia subtypes were detailed ${ }^{10}$. This brief overview of the history of the frontotemporal dementia (FTD) description provides a sense of how recently clinical presentations of FTLD have been characterized, which in part accounts for the diagnostic difficulties encountered in clinical practice.

In parallel with advances in clinical characterization, mutations associated with FTLD have been identified since 1998, when mutations in the MAPT gene on chromosome 17 were first recognized in families with FTD and parkinsonism. Since the identification of MAPT mutations, over 10 other genes have been associated with FTD spectrum disorders and, surprisingly, a single genetic mutation was found to account for completely different clinical pictures as well as for variable neuroimaging phenotypes ${ }^{11}$.
Despite this myriad of presentation possibilities, there is a clear tendency for a pattern of atrophy of the frontal and temporal brain regions. The main affected areas correspond to the medial frontal lobe and fronto-insular regions ${ }^{12}$. Temporal lobes are also frequently affected and are even the most common site of atrophy in MAPT mutation individuals. Contemporary neuroscience is still dedicated to understanding the reasons for this convergent topographic involvement, despite a heterogeneous pathological background. Even more incipient is the understanding of the neurobiological role played by these brain regions, which are affected very early in the degenerative process that characterizes the FTLD spectrum ${ }^{13}$, and can determine dramatically disturbing clinical presentations.

The frontal lobes and their multiple connections regulate essential aspects of human behavior, especially those resulting from the decision-making process. The frontal lobes also contribute to the processing of an additional repertoire of highly adaptive behaviors through afferents coming from the temporal lobes, especially from the polar region and the amygdala. The ability to regulate affective responses, adjusting them to the current social context and promoting adaptive prosocial attitudes, is also attributed to this interaction.

Such sophisticated behavioral adjustments are fundamental to a successful life, both from an individual and a societal point of view. This repertoire of behaviors is much vaster and ecologically far more relevant than the classical executive function performance, usually probed in artificially-set testing environments, through tasks relying on dorsolateral prefrontal cortex, which are heavily dependent on working memory and attentional control processes, and do not tap into the frontotemporal regions herein emphasized and critically important to FTD phenomenology. It is not surprising, therefore, that degenerative processes affecting these circuits, or psychiatric disorders that lead to their dysfunction, can be deeply disturbing to the patient's daily functioning, despite mildto-no impairment in classical neuropsychological tests. More recently, neuroimaging studies have demonstrated that there may be a common anatomo-functional underpinning between FTD and a few psychiatric conditions, at least in a small subset of patients ${ }^{14}$.

\section{SYSTEMATIC REVIEW}

\section{Methods}

Studies were selected from PubMed and LILACS databases, including those published up to February 12, 2018. The search strategy included the following terms: "frontotemporal dementia” plus "bipolar", OR "frontotemporal dementia" plus "schizophrenia", OR "frontotemporal dementia" plus "schizoaffective". Neither a publication date restriction nor a search field filter was used. This search strategy was 
augmented with manual searching through the reference lists from the included studies and was independently performed by two investigators (HCG and LBG).

Titles and abstracts of the papers - including publications ahead-of-print - retrieved in the initial search were screened and subsequently classified according to their own design characteristics: 1) case-control, 2) case reports, 3) cohort and 4) cross-sectional design studies. Publications without abstracts, case reports with absent genetic or histopathological confirmation, review articles, and papers written in nonEnglish languages were not selected across the systematic search process.

\section{RESULTS}

The Figure shows the selected studies and the Table presents their findings.

The research on PubMed retrieved 186 articles, of which 42 matched eligibility criteria. On LILACS, none of the nine retrieved met the requirements. Therefore, 42 articles were selected, of which 10 were cohort studies ${ }^{15,16,17,18,19,20,21,22,23,24}$, three were case-control studies ${ }^{25,26,27}, 12$ were case repo $\mathrm{rts}^{28,29,30,31,32,33,34,35,36,37,38,39}$ and 17 other studies were cross-sectional surveys $6,7,40,41,42,43,44,45,46,47,48,49,50,51,52,53,54$.

It was possible to identify three major research aims among the selected studies: 1) to look for FTLDassociated genetic abnormalities, mostly C9orf72 expansions, in psychotic, schizophrenic or bipolar patients; 2) to compare the cognitive profile between patients affected by neurodegenerative disorders and schizophrenic patients; 3 ) to highlight the association between bvFTD and preceding psychiatric conditions and/or distinguish them both

The C9orf72 expansion was detected in $0.67 \%$ of a SCZ/SZA sample $(\mathrm{n}=298)$ and in $0.57 \%$ of a sample of psychotic individuals $(n=697)(15,20)$. However, this expansion was not found in four other cohorts of BD $(n=206)$, SCZ $(n=192$, $\mathrm{n}=466)$ and in treatment-resistant SCZ $(\mathrm{n}=386)^{16,18,19,22}$. Cross-sectional studies comparing the neurocognitive profile between bvFTD and psychiatric disorders mostly found no remarkable differences ${ }^{44,45,47,53}$, or pointed to less severe deficits in bvFTD ${ }^{49,55}$. Lastly, there were several case reports that established a definite FTLD diagnosis, through genetic or histopathological examination, in patients with previous diagnoses or clinical histories compatible with BD/SCZ/SZA

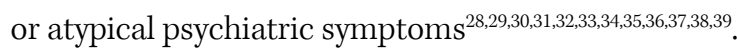

As shown in the Table, investigated mutations were found infrequently in the studied samples. Additionally, almost every large cohort studied did not look for mutations in a control group. The attempt to compare psychiatric disorders and neurodegenerative conditions clinically usually fails, considering that a few of these psychiatric patients might have already become demented by the time of the research evaluation, especially samples of severely affected individuals. Conversely, many case reports suggest a pathophysiological association between psychiatric disorders and FTLD, but more evidence is warranted to support this assumption.

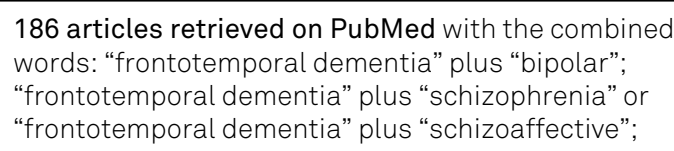

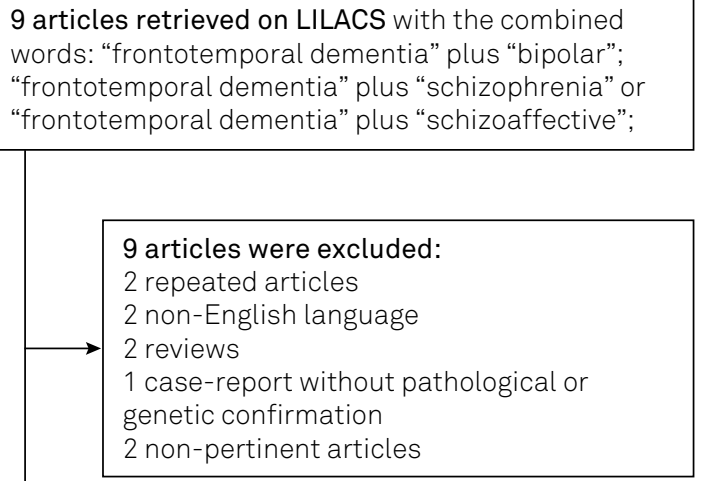


Table. Synthesis of articles included in the present review.

\begin{tabular}{|c|c|c|c|c|c|}
\hline Authors & $\begin{array}{l}\text { Sample } \\
\text { size }\end{array}$ & Participants & $\begin{array}{l}\text { Type of } \\
\text { study }\end{array}$ & Objectives & Results \\
\hline Watson A et al. ${ }^{15}, 2016$ & 739 & $\begin{array}{l}697 \text { with psychosis; } 42 \\
\text { base controls }\end{array}$ & Cohort & $\begin{array}{c}\text { To identify C9orf72 } \\
\text { expansion }\end{array}$ & $\begin{array}{c}\text { Two pairs of related } \\
\text { individuals had C9orf72 } \\
\text { expansions. }\end{array}$ \\
\hline Xu et al. $.^{16}, 2015$ & 386 & $\begin{array}{l}\text { Treatment-resistant } \\
\text { schizophrenia }\end{array}$ & Cohort & $\begin{array}{c}\text { To identify C9orf72 } \\
\text { expansion }\end{array}$ & $\begin{array}{l}\text { No abnormal hexanucleotide } \\
\text { expansion was found. }\end{array}$ \\
\hline $\begin{array}{l}\text { Boutoleau-Bretonnière } \\
\text { et al. } .^{7}, 2015\end{array}$ & 89 & $\begin{array}{c}36 \text { bvFTD; } 22 \\
\text { Alzheimer's disease; } \\
15 \text { progressive } \\
\text { supranuclear palsy; } 16 \\
\text { bipolar disorder }\end{array}$ & Cohort & $\begin{array}{l}\text { To produce a behavioral } \\
\text { inventory named DAPHNE. The } \\
\text { aim was (1) to assess the validity } \\
\text { and reliability of DAPHNE and } \\
\text { (2) to evaluate its contribution to } \\
\text { differentiating patients. }\end{array}$ & $\begin{array}{l}\text { DAPHNE-6 allowed bvFTD } \\
\text { diagnosis (score } 4 \text { ) with } \\
\text { a sensitivity of } 92 \% \text {, while } \\
\text { DAPHNE-40 (score } 15 \text { ) had a } \\
\text { specificity of } 92 \% \text {. }\end{array}$ \\
\hline Yoshino et al. ${ }^{18}, 2015$ & 466 & Schizophrenia & Cohort & $\begin{array}{c}\text { To identify C9orf72 } \\
\text { expansion }\end{array}$ & $\begin{array}{l}\text { No abnormal hexanucleotide } \\
\text { expansion was found. }\end{array}$ \\
\hline Floris et al. ${ }^{19}, 2014$ & 206 & Bipolar disorder & Cohort & $\begin{array}{c}\text { To identify C9orf72 } \\
\text { expansion }\end{array}$ & $\begin{array}{l}\text { No abnormal hexanucleotide } \\
\text { repeat expansion was found. }\end{array}$ \\
\hline Galimberti et al. ${ }^{20}, 2014$ & 298 & $\begin{array}{c}\text { Schizophrenia or } \\
\text { schizoaffective disorder }\end{array}$ & Cohort & $\begin{array}{l}\text { To identify C9orf72 } \\
\text { expansion }\end{array}$ & $\begin{array}{c}\text { The C9orf72 expansion } \\
\text { was detected in } 2 \text { patients } \\
(0.67 \%) \text {. }\end{array}$ \\
\hline Nicolas et al. ${ }^{21}, 2014$ & 96 & Schizophrenia & Cohort & $\begin{array}{l}\text { To accurately diagnose } \\
\text { dementia and its type in } \\
\text { a cohort of middle-aged } \\
\text { patients with SCZ }\end{array}$ & $\begin{array}{l}\text { Fourteen patients fulfilled } \\
\text { diagnostic criteria for } \\
\text { dementia. Four of them were } \\
\text { diagnosed with possible or } \\
\text { probable bvFTD. }\end{array}$ \\
\hline Huey et al. ${ }^{22}, 2013$ & 192 & Schizophrenia & Cohort & $\begin{array}{c}\text { To identify C9orf72 } \\
\text { expansion }\end{array}$ & $\begin{array}{l}\text { No abnormal hexanucleotide } \\
\text { repeat expansion was found. }\end{array}$ \\
\hline Meisler et al. ${ }^{23}, 2013$ & 89 & Bipolar disorder & Cohort & $\begin{array}{l}\text { To identify C9orf72 } \\
\text { expansion }\end{array}$ & $\begin{array}{l}\text { The expansion frequency in } \\
\text { this BD cohort was } 1 \% \text {. }\end{array}$ \\
\hline de Vries et al. ${ }^{24}, 2001$ & 8 & $\begin{array}{l}\text { Schizophrenia patients } \\
\text { with disorientation }\end{array}$ & Cohort & $\begin{array}{l}\text { To describe the } \\
\text { identification of dementia } \\
\text { following SCZ, not better } \\
\text { attributed to the psychiatric } \\
\text { disorder itself. }\end{array}$ & $\begin{array}{c}\text { Objective evidence of } \\
\text { dementia was found } \\
\text { in all patients, with a } \\
\text { neuropsychological signature } \\
\text { and SPECT findings similar } \\
\text { to bvFTD. }\end{array}$ \\
\hline Fahey et al. ${ }^{25}, 2014$ & $\begin{array}{l}2477 \\
\text { controls: } \\
\text { 1234; } \\
\text { cases: } \\
\text { 1243) }\end{array}$ & Psychosis & $\begin{array}{l}\text { Case- } \\
\text { control }\end{array}$ & $\begin{array}{c}\text { To compare the prevalence } \\
\text { of C9orf72 expansion } \\
\text { between psychosis patients } \\
\text { and controls }\end{array}$ & $\begin{array}{l}\text { No expansion }>30 \text { repeats } \\
\text { was found. Expansions }> \\
22 \text { repeats were similarly } \\
\text { prevalent among patients } \\
\quad \text { and controls. }\end{array}$ \\
\hline Bosia et al. ${ }^{26}, 2012$ & 315 & $\begin{array}{l}220 \text { schizophrenia; } 48 \\
\text { bvFTD; } 47 \text { controls }\end{array}$ & $\begin{array}{l}\text { Case- } \\
\text { control }\end{array}$ & $\begin{array}{l}\text { To evaluate the possible } \\
\text { role of the Saitohin (Tau } \\
\text { gene) polymorphism as } \\
\text { a concurring factor of } \\
\text { cognitive decline in SCZ }\end{array}$ & $\begin{array}{l}\text { No significant difference in } \\
\text { allelic distribution between } \\
\text { the healthy controls and } \\
\text { all other groups. Saitohin } \\
\text { polymorphism predicted } \\
\text { executive test performance in } \\
\text { both patient groups. }\end{array}$ \\
\hline Evin et al. ${ }^{27}, 2002$ & 46 & $\begin{array}{l}\text { Various } \\
\text { neurodegenerative } \\
\text { disorders }\end{array}$ & $\begin{array}{l}\text { Case- } \\
\text { control }\end{array}$ & $\begin{array}{l}\text { To analyze the expression } \\
\text { of AD-associated } \\
\text { presenilin } 1 \text { (PS1) in various } \\
\text { neurodegenerative disorders }\end{array}$ & $\begin{array}{l}\text { Identified PS1 N-and } \\
\text { C-terminal fragments } \\
\text { similarly in the cortex } \\
\text { of controls, Parkinson's, } \\
\text { Huntington's and } \\
\text { SCZ individuals. }\end{array}$ \\
\hline Rubino et al..28, 2017 & 1 & $\begin{array}{l}\text { An Italian male } \\
\text { presenting with late- } \\
\text { onset bipolar disorder }\end{array}$ & $\begin{array}{l}\text { Case } \\
\text { report }\end{array}$ & $\begin{array}{l}\text { To report a case suggesting } \\
\text { a possible link between BD, } \\
\text { FTD and GRN mutations }\end{array}$ & $\begin{array}{l}\text { In addition to FTD, } \\
\text { progranulin may be involved } \\
\text { in the neurobiology of BD } \\
\text { type 1. Suggestion to screen } \\
\text { patients with late-onset BD } \\
\text { for GRN mutations. }\end{array}$ \\
\hline Watanabe et al. ${ }^{29}, 2017$ & 1 & $\begin{array}{l}\text { A 58-year-old patient } \\
\text { who had a sudden } \\
\text { onset of disorganized } \\
\text { behavior and } \\
\text { meaningless speech. } \\
\text { Psychotropic drugs } \\
\text { were effective for } \\
\text { catatonic symptoms }\end{array}$ & $\begin{array}{l}\text { Case } \\
\text { report }\end{array}$ & $\begin{array}{c}\text { To report on a FTD patient } \\
\text { who showed catatonia after } \\
\text { the first episode of brief } \\
\text { psychotic disorder }\end{array}$ & $\begin{array}{l}\text { FTD with trans-activation } \\
\text { response DNA-binding } \\
\text { protein } 43 \text { presenting with a } \\
\text { catatonic syndrome. }\end{array}$ \\
\hline
\end{tabular}




\begin{tabular}{|c|c|c|c|c|c|}
\hline Authors & $\begin{array}{l}\text { Sample } \\
\text { size }\end{array}$ & Participants & $\begin{array}{l}\text { Type of } \\
\text { study }\end{array}$ & Objectives & Results \\
\hline Gramaglia et al. ${ }^{30}, 2014$ & 1 & $\begin{array}{c}\text { A 57-year-old } \\
\text { Caucasian woman with } \\
\text { a recent onset of bizarre } \\
\text { behavior and mystic } \\
\text { delusions }\end{array}$ & $\begin{array}{l}\text { Case } \\
\text { report }\end{array}$ & $\begin{array}{c}\text { To describe a patient with } \\
\text { bvFTD with a primary } \\
\text { psychiatric presentation } \\
\text { and a normal neurological } \\
\text { examination }\end{array}$ & $\begin{array}{c}\text { The C9orf72 expansion was } \\
\text { detected. }\end{array}$ \\
\hline Holm $^{31}, 2014$ & 1 & $\begin{array}{l}\text { A patient with traumatic } \\
\text { brain injury with } \\
\text { subsequent depression } \\
\text { and catatonia }\end{array}$ & $\begin{array}{l}\text { Case } \\
\text { report }\end{array}$ & $\begin{array}{l}\text { To describe a patient } \\
\text { with familial FTD with } \\
\text { a primary psychiatric } \\
\text { presentation, and typical } \\
\text { response to standard } \\
\text { treatment (lorazepam + } \\
\text { electroconvulsive therapy) } \\
\text { at the beginning }\end{array}$ & $\begin{array}{c}\text { The C9orf72 expansion was } \\
\text { detected. }\end{array}$ \\
\hline
\end{tabular}

A man who, from the age of 42 years, Floris et al. ${ }^{32}, 2013 \quad 1 \quad \begin{aligned} & \text { developed an affective } \\ & \text { disorder characterized }\end{aligned}$ by repeated manic and hypomanic episodes

\begin{tabular}{|c|c|c|c|c|c|}
\hline & & $\begin{array}{l}\text { by repeated manic and } \\
\text { hypomanic episodes }\end{array}$ & & Detween BU and FILU & \\
\hline Gourzis et al. ${ }^{33}, 2012$ & 1 & $\begin{array}{l}\text { A 29-year-old female } \\
\text { patient previously } \\
\text { diagnosed as having } \\
\text { schizophrenia }\end{array}$ & $\begin{array}{l}\text { Case } \\
\text { report }\end{array}$ & $\begin{array}{l}\text { To describe a young } \\
\text { patient suffering from FTD, } \\
\text { misdiagnosed as SCZ, } \\
\text { suggesting the association } \\
\text { between this clinical } \\
\text { phenotype with a genetic } \\
\text { defect on chromosome } 1\end{array}$ & $\begin{array}{l}\text { The diagnosis of FTD was } \\
\text { made clinically. Chromosomal } \\
\text { analysis was conducted and } \\
\text { revealed decrease in length } \\
\text { of heterochromatin on the } \\
\text { long arm of chromosome } 1 \\
\text { (46, XX, 1qh-). }\end{array}$ \\
\hline Khan et al. ${ }^{34}, 2012$ & 1 & $\begin{array}{l}\text { A 35-year old woman } \\
\text { who presented with } \\
\text { new-onset of bizarre } \\
\text { behavior and delusions }\end{array}$ & $\begin{array}{l}\text { Case } \\
\text { report }\end{array}$ & $\begin{array}{l}\text { To make physicians aware } \\
\text { of the potential overlapping } \\
\text { symptoms and age at onset } \\
\text { between some forms of } \\
\text { bvFTD and SCZ }\end{array}$ & $\begin{array}{l}\text { The patient was found to have } \\
\text { a MAPT tau S356T mutation } \\
\text { and a focal pattern of brain } \\
\text { atrophy consistent with FTD. }\end{array}$ \\
\hline Cerami et al. ${ }^{35}, 2011$ & 2 & $\begin{array}{l}\text { Two apparently- } \\
\text { sporadic FTLD patients, } \\
\text { with a premorbid } \\
\text { bipolar disorder }\end{array}$ & $\begin{array}{l}\text { Case } \\
\text { report }\end{array}$ & $\begin{array}{c}\text { To report two patients } \\
\text { of definite FTLD with } \\
\text { premorbid psychiatric } \\
\text { symptoms }\end{array}$ & $\begin{array}{l}\text { Medical history and genetic } \\
\text { investigation revealed the } \\
\text { presence of bipolar spectrum } \\
\text { disorders and mutations in } \\
\text { the GRN gene. }\end{array}$ \\
\hline Momeni et al. ${ }^{36}, 2010$ & 2 & $\begin{array}{l}\text { A Latino family in which } \\
\text { two siblings were } \\
\text { diagnosed as having } \\
\text { either schizophrenia } \\
\text { or frontotemporal } \\
\text { dementia }\end{array}$ & $\begin{array}{l}\text { Case } \\
\text { report }\end{array}$ & $\begin{array}{c}\text { To characterize GRN } \\
\text { mutations in the affected } \\
\text { individuals }\end{array}$ & $\begin{array}{l}\text { The siblings both have loss- } \\
\text { of-function GRN mutations. }\end{array}$ \\
\hline Momeni et al. ${ }^{37}, 2010$ & 2 & $\begin{array}{l}\text { Familial FTD with an } \\
\text { exceptionally early } \\
\text { age at onset. Both } \\
\text { the proband and the } \\
\text { proband's father were } \\
\text { initially diagnosed as } \\
\text { having schizophrenia }\end{array}$ & $\begin{array}{l}\text { Case } \\
\text { report }\end{array}$ & $\begin{array}{l}\text { To report a novel exon } 12 \\
\text { mutation in MAPT (S356T) } \\
\text { causing familial bvFTD }\end{array}$ & $\begin{array}{l}\text { Pathological examination } \\
\text { showed FTLD with } \\
\text { extensive neuronal and glial } \\
\text { tau deposition. }\end{array}$ \\
\hline Stone et al. ${ }^{38}, 2003$ & 1 & $\begin{array}{l}\text { A 22-year-old man } \\
\text { who had presented six } \\
\text { years previously with } \\
\text { symptoms that were } \\
\text { initially attributed to } \\
\text { schizophrenia }\end{array}$ & $\begin{array}{l}\text { Case } \\
\text { report }\end{array}$ & $\begin{array}{l}\text { To report on a patient and } \\
\text { to raise awareness that } \\
\text { FTD should be considered } \\
\text { in patients in their early } \\
20 \text { s with SCZ and negative } \\
\text { symptoms, who display } \\
\text { frontotemporal dysfunction } \\
\text { and have a relentlessly } \\
\text { progressive course }\end{array}$ & $\begin{array}{l}\text { Magnetic resonance imaging } \\
\text { and neuropathology obtained } \\
\text { at brain biopsy suggest a } \\
\text { diagnosis of non-Pick's FTD. }\end{array}$ \\
\hline Waddington et al. ${ }^{39}, 1995$ & 1 & $\begin{array}{l}\text { A woman with a } \\
\text { consistent clinical } \\
\text { diagnosis of typical } \\
\text { schizophrenia }\end{array}$ & $\begin{array}{l}\text { Case } \\
\text { report }\end{array}$ & $\begin{array}{l}\text { To report on a patient and to } \\
\text { report 'schizophrenia-like' } \\
\text { psychosis as a prodrome of } \\
\text { Pick's disease }\end{array}$ & $\begin{array}{c}\text { The neuropathological } \\
\text { hallmarks of Pick's disease } \\
\text { were present. }\end{array}$ \\
\hline
\end{tabular}
To report on a patient
Case
suggesting a possible link suggesting a possible link
between $B D$ and FTLD

The C9orf72 expansion was detected.

Continue 


\begin{tabular}{|c|c|c|c|c|c|}
\hline Authors & $\begin{array}{l}\text { Sample } \\
\text { size }\end{array}$ & Participants & $\begin{array}{l}\text { Type of } \\
\text { study }\end{array}$ & Objectives & Results \\
\hline Baez et al. ${ }^{40}, 2019$ & 51 & $\begin{array}{l}16 \text { bvFTD/ } 13 \text { Bipolar } \\
\text { disorder/ } 22 \text { controls }\end{array}$ & $\begin{array}{l}\text { Cross } \\
\text { sectional }\end{array}$ & $\begin{array}{l}\text { The compare the executive } \\
\text { functions (EF) and social } \\
\text { cognition profiles as well as } \\
\text { the structural neuroimaging } \\
\text { of bvFTD and elderly } \\
\text { patients with BD. }\end{array}$ & $\begin{array}{l}\text { bvFTD patients showed } \\
\text { deficits in working memory, } \\
\text { abstraction capacity, } \\
\text { inhibitory control, cognitive } \\
\text { flexibility, verbal fluency and } \\
\text { theory of mind (ToM). Patients } \\
\text { with BD showed lower } \\
\text { performance than controls in } \\
\text { terms of abstraction capacity } \\
\text { and verbal inhibitory control. } \\
\text { In bvFTD patients, atrophy } \\
\text { of frontal, temporal and } \\
\text { insular cortices was related } \\
\text { to EF deficits. Atrophy of the } \\
\text { amygdala, the hippocampus, } \\
\text { the parahippocampal gyrus, } \\
\text { the putamen, the insula, } \\
\text { the precuneus, the right } \\
\text { temporo-parietal junction } \\
\text { and superior temporal pole } \\
\text { was associated to ToM } \\
\text { impairments. No significant } \\
\text { associations between } \\
\text { atrophy and EF performance } \\
\text { were observed in BD } \\
\text { patients. BvFTD patients } \\
\text { showed greater EF and ToM } \\
\text { deficits than BD patients. } \\
\text { Moreover, compared to BD, } \\
\text { bvFTD patients exhibited a } \\
\text { significant decrease in GM } \\
\text { volume in frontal, temporal } \\
\text { and parietal regions }\end{array}$ \\
\hline Metin et al. ${ }^{41}, 2018$ & 38 & $\begin{array}{l}18 \text { bvFTD/ } 20 \text { late-life } \\
\text { Bipolar disorder }\end{array}$ & $\begin{array}{l}\text { Cross } \\
\text { sectional }\end{array}$ & $\begin{array}{l}\text { To compare differential } \\
\text { diagnosis ability of } \\
\text { electrophysiological and } \\
\text { neuroimaging findings in } \\
\text { BD and bvFTD, aimed to } \\
\text { show their classification } \\
\text { power using an artificial } \\
\text { neural network and genetic } \\
\text { algorithm based approach }\end{array}$ & $\begin{array}{l}\text { The artificial neural network } \\
\text { method classified BD from } \\
\text { bvFTD with } 76 \% \text { overall } \\
\text { accuracy only by using } \\
\text { on EEG power values. The } \\
\text { radiological diagnosis } \\
\text { classified BD from bvFTD } \\
\text { with } 79 \% \text { overall accuracy. } \\
\text { The radiological diagnosis } \\
\text { added to the EEG analysis, } \\
\text { classifiied with } 87 \% \\
\text { overall accuracy. }\end{array}$ \\
\hline Vijverberg et al. ${ }^{42}, 2017$ & 381 & $\begin{array}{l}42 \text { major depression/ } \\
41 \text { Bipolar disorder/ } \\
47 \text { schizophrenia/ } 173 \\
\text { bvFTD/ } 78 \text { controls }\end{array}$ & $\begin{array}{l}\text { Cross } \\
\text { sectional }\end{array}$ & $\begin{array}{l}\text { To compare neuropsychological } \\
\text { profiles in bvFTD with its most } \\
\text { common primarypsychiatric } \\
\text { differential diagnoses. }\end{array}$ & $\begin{array}{l}\text { Cognitive deficits in bvFTD } \\
\text { are less severe than in } \\
\text { primary psychiatric disorders } \\
\text { with active symptoms. }\end{array}$ \\
\hline Devenney et al. ${ }^{43}, 2016$ & 79 & $\begin{array}{c}56 \text { bvFTD/ } 23 \text { healthy } \\
\text { controls }\end{array}$ & $\begin{array}{l}\text { Cross } \\
\text { sectional }\end{array}$ & $\begin{array}{l}\text { To address the gap in the } \\
\text { literature regarding the } \\
\text { severity and underlying } \\
\text { neural correlates of } \\
\text { psychotic symptoms in } \\
\text { frontotemporal dementia } \\
\text { with and without the } \\
\text { c9orf72 gene expansion }\end{array}$ & $\begin{array}{l}\text { 34\% of bvFTD showed } \\
\text { psychotic features. C9orf72 } \\
\text { expansion cases were } \\
\text { more likely to exhibit } \\
\text { psychotic symptoms than } \\
\text { non-carriers ( } 64 \% \text { vs. } \\
26 \% ; p=0.006) \text {. Increased } \\
\text { psychotic symptoms in } \\
\text { C9orf72 expansion carriers } \\
\text { correlated with atrophy in } \\
\text { a distributed cortical and } \\
\text { subcortical network that } \\
\text { included discrete regions } \\
\text { of the frontal, temporal and } \\
\text { occipital cortices, as well } \\
\text { as the thalamus, striatum } \\
\text { and cerebellum. }\end{array}$ \\
\hline
\end{tabular}




\begin{tabular}{|c|c|c|c|c|}
\hline Authors & $\begin{array}{l}\text { Sample } \\
\text { size }\end{array}$ & Participants & $\begin{array}{l}\text { Type of } \\
\text { study }\end{array}$ & Objectives \\
\hline Chan et al. ${ }^{44}, 2015$ & 50 & $\begin{array}{l}7 \text { inpatients with } \\
\text { schizophrenia/ } 13 \\
\text { community-dwelling } \\
\text { outpatients with } / 12 \\
\text { bvFTD/ } 18 \text { healthy } \\
\text { controls }\end{array}$ & $\begin{array}{c}\text { Cross } \\
\text { sectional }\end{array}$ & $\begin{array}{l}\text { To compare neurocognitive } \\
\text { performance across groups } \\
\text { in } 16 \text { cognitive domains }\end{array}$ \\
\hline Chan et al. ${ }^{45}, 2014$ & 60 & $\begin{array}{c}26 \text { schizophrenia/ } 34 \\
\text { bvFTD }\end{array}$ & $\begin{array}{c}\text { Cross } \\
\text { sectional }\end{array}$ & $\begin{array}{c}\text { To compare retrospectively } \\
\text { the neuropsychological } \\
\text { performance of } \\
\text { schizophrenia and } \\
\text { frontotemporal dementia } \\
\text { patients. }\end{array}$ \\
\hline
\end{tabular}

18 mild FTD/ 20

Nishida et al. ${ }^{46}, 2013$

93 schizophrenia/ 18 mild Alzheimer's disease/ 37 age matched controls
Cross sectional patterns, related to restingstate fMRI networks, among groups.
To compare resting EEG

Results

Their findings revealed a similar cognitive profile among schizophrenia inpatients and bvFTD groups, compared with schizophrenia outpatients' group, which outperformed the former two groups.

Cognitive impairment was similar in degree and pattern between groups.

The duration of class $C$ was significantly shorter in FTD than in controls and $A D$, and the duration of class D was significantly shorter in schizophrenia than in controls, FTD and AD

\begin{tabular}{|c|c|c|c|c|}
\hline Weickert et al. ${ }^{47}, 2013$ & 70 & $\begin{array}{c}20 \text { FTLD/24 } \\
\text { schizophrenia/ } 26 \\
\text { controls }\end{array}$ & $\begin{array}{c}\text { Cross } \\
\text { sectional }\end{array}$ & $\begin{array}{l}\text { To investigate and } \\
\text { compare probabilistic } \\
\text { association learning } \\
\text { between schizophrenia and } \\
\text { FTLD patients. }\end{array}$ \\
\hline Bediou et al. ${ }^{48}, 2012$ & 214 & $\begin{array}{l}\text { Several neurodegerative } \\
\text { disorders and } \\
\text { schizophrenia patients }\end{array}$ & $\begin{array}{c}\text { Cross } \\
\text { sectional }\end{array}$ & $\begin{array}{l}\text { To compare Facial } \\
\text { Emotion Recognition test } \\
\text { performance acrros several } \\
\text { groups, and invetsigate the } \\
\text { influece of dopaminergic } \\
\text { drugs on these findings. }\end{array}$ \\
\hline Woolley et al.?, 2011 & 252 & $\begin{array}{c}\text { Several } \\
\text { neurodegenerative } \\
\text { disorders }\end{array}$ & $\begin{array}{c}\text { Cross } \\
\text { sectional }\end{array}$ & $\begin{array}{l}\text { To identify rates of } \\
\text { and risk factors for } \\
\text { psychiatric diagnosis } \\
\text { preceding the diagnosis } \\
\text { of neurodegenerative } \\
\text { disease, retrospectively by } \\
\text { chart review. }\end{array}$ \\
\hline
\end{tabular}

To compare clinical and neuropsychological features between schizophrenia patients with predominant negative symtoms and bvFTD.
There was no difference in performance between FTLD and schizophrenia groups.

FTD patients presented the worst performance across all groups. Symtpomatic schizophrenia patients standed between FTD and AD groups, and as simililar as Parkinson's disease patients.

bvFTD patients received a prior psychiatric diagnosis significantly more often than other dementia types and were also more likely to receive a diagnosis of bipolar disorder or schizophrenia.

Negative and frontal lobe symptoms were similarly present in both groups.

Negative scores were higher in schizophrenia and frontal lobe behaviors were more pronounced in bvFTD.

The morbid risk for schizophrenia was significantly higher in relatives of frontotemporal dementia probands

Analysis showed unique patterns of spared function in when compared to FTD and controls

Five out of 17 patients had presented psychotic symptoms.
Patients with bvFTD

Velakoulis et al. ${ }^{6}, 2009$

17 who had symptoms onset before 60 years.
Cross sectional
To address whether measures for assessing premorbid intellectual

functioning are adequate for geriatric schizophrenia

To investigate the relationship between early age at onset and psychotic presentations in pathologically verified definiter bvFTD patients. 


\begin{tabular}{|c|c|c|c|c|c|}
\hline Authors & $\begin{array}{l}\text { Sample } \\
\text { size }\end{array}$ & Participants & $\begin{array}{l}\text { Type of } \\
\text { study }\end{array}$ & Objectives & Results \\
\hline Velakoulis et al. ${ }^{52}, 2009$ & 23 & $\begin{array}{c}\text { 12 Schizphrenia/ } 3 \\
\text { Bipolar disorder/ } 11 \\
\text { controls }\end{array}$ & $\begin{array}{c}\text { Cross } \\
\text { sectional }\end{array}$ & $\begin{array}{c}\text { To determine whether } \\
\text { FTD-like abnormalities in } \\
\text { TARDNA binding protein } \\
\text { (TDP-43) and ubiquitin are } \\
\text { detectable in hippocampal } \\
\text { dentate gyrus of patients } \\
\text { with schizophrenia and } \\
\text { bipolar disorder }\end{array}$ & $\begin{array}{l}\text { The regular nuclear } \\
\text { expression of TDP- } 43 \text { was not } \\
\text { detected in } 3 \text { patients. }\end{array}$ \\
\hline Foley et al. ${ }^{53}, 2008$ & 185 & $\begin{array}{c}37 \text { geriatric } \\
\text { schizophrenia- } \\
\text { spectrum disorders / } 41 \\
\text { bvFTD / } 107 \text { controls }\end{array}$ & $\begin{array}{c}\text { Cross } \\
\text { sectional }\end{array}$ & $\begin{array}{l}\text { To investigate pattern of } \\
\text { memory deficits across } \\
\text { groups. }\end{array}$ & $\begin{array}{l}\text { Failed to find differences } \\
\text { between groups on pattern of } \\
\text { memory impairment. }\end{array}$ \\
\hline Kosmidis et al. ${ }^{54}, 2008$ & 63 & $\begin{array}{c}28 \text { schizophrenia } \\
\text { plus } 26 \text { age-matched } \\
\text { controls / } 9 \text { bvFTD } \\
\text { plus } 10 \text { age-matched } \\
\text { controls }\end{array}$ & $\begin{array}{c}\text { Cross } \\
\text { sectional }\end{array}$ & $\begin{array}{l}\text { To investigate social } \\
\text { cognition and theory of } \\
\text { mind across groups using } \\
\text { videotaped scenarios of } \\
\text { social interactions. }\end{array}$ & $\begin{array}{l}\text { Both groups displayed } \\
\text { generalized impairments } \\
\text { in comprehension of social } \\
\text { interactions. Schizophrenia } \\
\text { patients were not impaired } \\
\text { in evaluating sincere } \\
\text { remarks. bvFTD patients } \\
\text { were markedly impaired } \\
\text { in recognizing sarcasm, } \\
\text { specially when non-verbal } \\
\text { cues were minimal. }\end{array}$ \\
\hline
\end{tabular}

bvFTD: behavioral variant frontotemporal dementia; FTLD: frontotemporal lobe dementia; FTD: frontotemporal dementia; SCZ: schizophrenia; BD: bipolar disorder; AD: Alzheimer's disease.

\section{DISCUSSION}

Most of the evidence gathered from the systematic review process does not clarify the link between lifelong SMI and dementia, precluding reliable assumptions regarding this disputed issue. Nevertheless, a few studies suggested the possibility, under a structured diagnostic proposal, of formally recognizing an equivalent to dementia syndrome in selected psychiatric patients.

Here we present a critical analysis, combining the main findings of this review and other related publications in the field suggesting directions for future research.

\section{Severe mental illness natural outcomes}

Making a diagnosis of dementia in a patient with lifelong SMI is challenging. Cognitive and functional impairment constitute plausible outcomes from the premorbid mental illness itself and impairment in cognitive performance does not exclude primary psychiatric diagnoses in a dementia workup ${ }^{42}$. Indeed, long-term cognitive and functional outcomes from severe psychiatric illness-BD, SZA or SCZ-are still a source of an intense debate. Accordingly, the fifth edition of the Diagnostic and Statistical Manual of Mental Disorders (DSM-5), in its "Functional Consequences of Bipolar I and II Disorders" topics, recognizes functional impairment in approximately $30 \%$ of patients with BD type I and in at least $15-20 \%$ of those with BD type II. The DSM-5 also reserves a topic to discuss the "Functional Consequences of Schizophrenia" and states that significant social and functional impairment are associated with $\mathrm{SCZ}^{55}$.
The very concept of SCZ emerged in 1896, with Kraepelin's description of dementia praecox. He emphasized the progressive nature of the disease, which almost invariably proceeded to cognitive and behavioral deterioration. At that time, the unfortunate prognosis associated with this disorder seemed to suggest to him the idea of a possible neurodegenerative condition. Additionally, in the so-called manic-depressive insanity, Kraepelin noticed the relapsing nature of mood disorders; however, recognizing the ordinary possibility of full recovery between depressive or manic episodes. Nevertheless, within a scenario of decreasing intercrisis intervals and increasing duration of episodes along the disease course, Kraepelin considered a worse prognosis, admitting the possibility of a "psychic decline" in these patients. It is interesting to point out that Kraepelin's description of patients with chronic mania share many behavioral features that constitute core diagnostic symptoms of bvFTD ${ }^{56}$.

In SCZ, the remission rate from a first psychotic episode is estimated to be around $70 \%$ in the first year but remains almost unchanged over the course of the disease. Functional recovery is less frequently achieved (18-40\%), namely living independently without psychotic or negative symptoms while working or studying, but this rate does not change over time, contradicting the idea of a progressive condition. Patients with psychotic disorders showed IQ deficits and developmental delays in specific cognitive domains during the first two decades of life, in a cohort study ${ }^{57}$. Hence, the cognitive impairment of these patients is suggested to be linked to a neurodevelopmental cause. 
In cognitive testing, patients with well-controlled SCZ usually display performances between 1.0 and 1.5 standard deviations below a reference control group ${ }^{58}$. This deficit corresponds to a mild neurocognitive disorder and is generally incompatible with dementia, where performance is typically 2.0 standard deviations or more below the mean, according to the DSM- $5^{55}$. Conversely, approximately $25 \%$ of SCZ patients can be categorized as having a poor cognitive and functional prognosis. Nonetheless, studies that have addressed this issue have not ventured into characterizing a formal diagnosis of dementia in these individuals ${ }^{59}$. The group with a poor outcome would encompass "Kraepelinian" SCZ, with permanent cognitive impairment and performance similar to bvFTD patients ${ }^{44}$. In searching for the overlapping diagnosis of dementia and SCZ, Nicolas et al. found 14 individuals who fulfilled the criteria for dementia in a cohort of $96 \mathrm{SCZ}$ patients followed for 20 months. Interestingly, four of them met criteria for bvFTD ${ }^{21}$.

Schizophrenic patients usually have social cognition disturbances as a manifestation of the illness. Therefore, Kosmidis and colleagues compared bvFTD and SCZ individuals using videotaped scenarios of social interactions illustrating sincere, sarcastic and paradoxical statements. The results indicated that the SCZ group had impaired performances on all theory of mind conditions, despite understanding sincere statements. Nonetheless, bvFTD patients had remarkable impairment in identifying sarcasm, and seemed to benefit from verbal tips that indicated the appropriate social context, suggesting that these patients were particularly impaired in detecting discrete nonverbal signs from the scene ${ }^{54}$. In another study, Bediou et al. explored facial emotional recognition performance in different clinical conditions, including SCZ and bvFTD. Their results showed impaired efficiency in both groups of patients when compared with their respective controls. The bvFTD group displayed poorer performance in comparison with the SCZ group ${ }^{48}$.

Patients with BD seem to present with cognitive impairment in all phases of the disease, including periods of remission, and it has been suggested that cognitive performance declines according to the number of accumulated mood disorder episodes ${ }^{60}$. Patients with BD share a similar cognitive profile with those with SCZ, including impairment in verbal memory, as well as in executive function and verbal fluency tests. Despite this similarity, there seems to be a severity spectrum across these disorders, in which $\mathrm{BD}$ patients display a better performance than those with SCZ, and SZA patients stand in between them ${ }^{58}$.

\section{Overlapping disorders}

\section{Psychiatric presentations in bvFTD}

Personality changes and inappropriate social behaviors are core features of bvFTD, including decline in interpersonal and social conduct, emotional blunting and loss of insight. Almost routinely, the behavioral symptoms precede marked cognitive decline. As a result, patients with early behavioral changes of bvFTD are more likely to seek specialized psychiatric help and usually receive a cardinal psychiatric disorder diagnosis ${ }^{6}$. In this sense, the use of a behavioral inventory appears to be the best assessment method to diagnose bvFTD ${ }^{17}$.

Some of the initial symptoms of bvFTD, such as apathy, disinterest and lack of initiative, are often mistakenly diagnosed as major depression. On the other hand, disinhibition, hypersexuality, compulsive behaviors and decreased need for sleep may be confused with the mania/hypomania symptoms of BD. Indeed, after major depressive disorder, BD was the most frequently-given diagnosis in a cohort of bvFTD patients, of whom almost $50 \%$ were diagnosed with a primary psychiatric disorder before bvFTD was finally recognized ${ }^{7}$. It is worth noting that Gossink and colleagues found different results (past psychiatric disorder in only $8.7 \%$ of individuals), albeit using a different set of inclusion criteria. They prospectively evaluated the prevalence of a past psychiatric disorder in a large cohort of bvFTD in a structured interview ${ }^{61}$. Nonetheless, this study did not consider the severe lack of insight in patients with bvFTD, and investigated the past psychiatric history of the patients by interviewing them directly, without the contribution of a trustworthy proxy.

Psychotic symptoms have been reported in about 10-20\% of bvFTD patients ${ }^{6}$, in spite of this not being considered a core symptom in diagnostic criteria. Therefore, this presentation may easily be mistaken for schizophrenic symptoms, particularly in those with C9orf72 gene expansions ${ }^{43}$. The emotional blunting displayed by bvFTD patients is akin to the one classically described by Bleuler in the "Group of Schizophrenias", a cluster of symptoms later categorized as part of the negative presentation of the disease in 1974. In 1988, Weinberger noted that those symptoms were "phenomenologically similar to many of the characteristics of patients with disease of the frontal lobe", later confirmed by Ziauddeen and colleagues ${ }^{49}$.

In fact, primary psychiatric disorders and bvFTD may be almost indistinguishable under the concept of late-onset frontal lobe syndrome. Vijverberg and colleagues have investigated which demographic, clinical, neuropsychological, neuroimaging, and CSF biomarkers are important in distinguishing primary psychiatric disorders presenting as lateonset frontal lobe syndrome, from bvFTD 9 . These authors suggested that late-onset primary psychiatric disorders may show neuroimaging abnormalities, especially metabolic deficits akin to FTD $^{63}$, in FDG-PET, which poses further difficulty in obtaining a correct differential diagnosis on a cross-sectional basis. Nevertheless, they found that specific CSF biomarkers - total tau, phosphorylated tau, amyloid- $\beta$ 1-42 peptide and neurofilament light chain concentrations-may aid clinicians in the diagnostic workup(64). Also, in an attempt to contribute to the distinction between primary psychiatric 
disorders and bvFTD, Metin and colleagues used quantitative electroencephalography for differentiating bvFTD from late-life $\mathrm{BD}$ with $76 \%$ overall accuracy ${ }^{41}$.

\section{Definite FTLD disguised as primary psychiatric disorders}

Velakoulis et al. $^{6}$ hypothesized that very young-onset bvFTD could masquerade as a SCZ or BD presentation. In a clinicopathological study, they found that five out of 17 FTLD patients had received a previous diagnosis of psychotic illness. Genetic analysis in one of these patients showed a mutation in the GRN gene. Additionally, in their literature review, the authors also found that a third of FTD patients aged 30 years or less, and a quarter of those aged 40 years or less, had received a primary diagnosis of psychosis ${ }^{6}$. Indeed, early-onset bvFTD patients, whose presentation included psychotic symptoms, social withdrawal, emotional blunting, functional decline and mild executive dysfunction, were likely to have received a diagnosis of SCZ.

Velakoulis et al. ${ }^{52}$ also investigated the presence of TDP43 neuropathology, related to FTLD, in brain sections of 12 deceased SCZ and BD patients. They identified three individuals with TDP-43 neuropathological changes. Interestingly, all three individuals had late-onset psychotic features, notable impairment in decision-making and a positive family history for $\mathrm{SMI}^{52}$, similar to bvFTD. Following the same reasoning, Meisler and colleagues demonstrated that the C9orf72 repeat expansion may be associated with a classic clinical presentation of BD and a later progression to neurodegenerative disease ${ }^{23}$. The same mutation was considered a possible, albeit rare, cause of SCZ in European and North American cohorts $^{15,20}$. Conversely, this mutation was not found in three other studies, two of them in Asian cohorts ${ }^{16,18,22}$.

There are frequent reports of lifelong psychiatric disorders, especially BD, describing patients in whom a definite bvFTD diagnosis was made through the identification of fully penetrant genetic abnormalities (C9orf72 and GRN), suggesting the possibility of a diagnostic superimposition of these two conditions, and the need for a debate on the relationship between them ${ }^{28,32,35}$. In the pursuit of the association between FTLD and primary psychiatric disorders, Schoder and colleagues investigated the risk of SCZ and SZA in first-degree relatives of patients with FTLD, and found a higher risk in this group of individuals in comparison with relatives of $\mathrm{AD}$ patients ${ }^{50}$.

\section{Neuroprogression models in severe mental illness and the neuroinflammatory pathway}

Increased blood levels of a wide range of cytokines in patients with primary psychiatric disorders, such as depression, BD and SCZ, have been documented, indicating a possible role of pro-inflammatory pathway neurotoxicity ${ }^{65}$.

In SCZ, neurotoxicity associated with a psychotic crisis was suggested by Wyatt ${ }^{66}$. Moreover, the duration of untreated symptoms has been correlated to a reduction of gray matter volumes in several reports ${ }^{67}$. Although neuroimaging studies showed structural developmental changes in the first psychotic episode, with subsequent reduction in brain tissue volume over the years, secondary causes, such as use of antipsychotics and other drugs, could alternatively explain the observed atrophy ${ }^{68}$.

In $\mathrm{BD}$, there have been increasing suggestions that chronic inflammatory processes, both from periphery and within the brain, are involved in its pathophysiology. Post proposed the foundations of our current knowledge regarding neuroprogression ${ }^{69}$. This phenomenon was further elaborated on by Kapczinski et al. to explain long-term outcomes of BD in brain structure, patient cognition, functionality and response to treatments ${ }^{70}$. It is noteworthy that the neuroprogression and staging models of severe psychiatric disorders accepted stages compatible with a diagnosis of dementia late in the course of these diseases ${ }^{70}$. These are theoretical models that do not clarify the mechanism that underpins this impressive change in the disease course. They also fail to contemplate the possibility that another superimposed disease might be in progress. Additionally, these models do not elucidate why many individuals do not progress to dementia as an end-stage BD.

Dols and colleagues described four patients with lifetime $\mathrm{BD}^{71}$ who evolved to a bvFTD phenotype, showing a behavioral profile very different from these individuals' previous levels of functioning. The authors admitted that the clinical picture could not be better explained by the patients' primary psychiatric disease course nor could it be explained by BD staging models, as the patients had few prior severe mood disorder episodes. The authors did not propose a neurodegenerative condition as a reliable explanation for their findings. After all, their patients had cognitive performances that were regarded as only mildly impaired, had no neuroimaging abnormalities, and did not show cognitive decline during follow-up. It is noteworthy that our group retrospectively studied patients with a similar clinical history to Dols ${ }^{71}$, but in the findings by Gambogi et al. ${ }^{72}$, including neuroimaging and cognitive testing, there were only subtle differences in a typical bvFTD patient. Gambogi et al. found that the frequency of antipsychotic drug use, primitive reflexes, apathy, stereotypic/compulsive/ritualistic behaviors, and family history of psychosis were statistically higher in bvFTD patients with a prior history of SMI than in patients with typical bvFTD. The former group of patients also showed a higher severity of neuropsychiatric symptoms and worse performance in the Frontal Assessment Battery ${ }^{72}$.

Unfortunately, studies of progressive neuroimaging changes in BD patients showed unreplicated and contradictory findings, such as increased gray matter volume in the prefrontal cortex, limbic and subcortical structures ${ }^{73}$. On the other hand, some reports pointed to a decrease in gray matter volume in orbital and medial prefrontal cortex, in addition to 
smaller volumes in medial temporal cortex and ventral striatum $^{74}$. Moreover, some patients may have greater volumes in the third and fourth ventricles, and these structural changes tend to be worse in patients with recurrent episodes ${ }^{75}$.

Although the effective interplay between peripheral mediators and the inflammatory phenomena of brain tissue is not precisely known, the intense communication between circulating cytokines and leukocytes and the central nervous system is undisputed nowadays. This phenomenon is processed across the blood-brain barrier through intense communication among neurons, glial cells and endothelial cells, whose luminal surface is in permanent contact with the vascular content ${ }^{76}$. In fact, the role of inflammatory tissue activation in the vicinity of neuropathological markers of classic neurodegenerative diseases has been recognized for some time ${ }^{77}$. Furthermore, animal models of some of these diseases have shown that the peripheral inflammatory stimulus may aggravate previous cognitive deficits, and even accelerate the neuropathological process per se. In prospective studies with elderly human cohorts, documentation of episodic systemic infection, such as pneumonia, increased the subsequent incidence of dementia ${ }^{78}$. Furthermore, in observational studies the use of nonsteroidal anti-inflammatory drugs was found to be associated with lower risk for dementia in exposed individuals ${ }^{78}$.

These combined data suggest that systemic inflammatory factors, with SCZ or BD hypothetically included, may contribute to the phenomenon of progressive cognitive decline.

\section{Atypical presentations of FTLD}

Recently, it has become possible to identify individuals carrying genetic mutations or expansions. Hence, a range of possibilities for research in FTLD has been opened, allowing in vivo investigation of endophenotypes in carrier individuals who do not yet present with the clinical disease itself. Studies comparing supposed asymptomatic MAPT mutation carriers with controls have highlighted brain connectivity changes years before the expected disease onset, according to their affected relatives' average clinical course ${ }^{79}$. Interestingly, connectivity changes share a similar topography with brain regions classically targeted by atrophy in symptomatic individuals. Indeed, the idea of SCZ as a prodrome of a neurodegenerative disease had already been proposed by Waddington et al. ${ }^{39}$ and by Khan et al. ${ }^{34}$ The former study established all the neuropathological hallmarks of Pick's disease in a biopsy from a woman with a typical schizophrenic picture ${ }^{39}$. The latter study confirmed MAPT mutation in a 35-year-old patient with an initial schizophreniform presentation and typical pattern of brain atrophy $y^{34}$.

Symptomatic patients carrying GRN mutations show reduced plasma progranulin levels and this same finding was evident in asymptomatic carriers in their second or third decades of life. In addition, mutations in the GRN gene had already been linked to SCZ and BD, with equal reduction of plasma protein levels in carriers ${ }^{36}$. Moreover, both MAPT and $G R N$ genes mutation carriers may exhibit structural and functional connectivity changes that precede the first symptoms of bvFTD. These changes are characterized by progressive reduction of fractional anisotropy through diffusion tensor imaging, and resemble abnormalities found in patients with BD, especially in the uncinate fasciculus ${ }^{80}$. These findings support the idea that psychiatric manifestations could be the prodromal phase of neurodegenerative diseases.

The definite confirmation of a pathological substrate associated with FTLD in patients with a psychiatric history, and the inversely proportional relationship between age at onset and the schizophreniform presentation (the younger, the more prevalent the presentations), suggest the possibility of a phenomenon already observed in other neurodegenerative diseases such as leukodystrophy and Niemann-Pick Type $\mathrm{C}$ disease. For reasons still not understood, these diseases sometimes manifest in adults or in the elderly, indicating a slow progression. It is reasonable to consider that psychosis might be a nonspecific psychiatric symptom, resulting from the reaction of the still-resilient young brain to the underlying neurodegenerative process.

Finally, the slowly-progressive degenerative phenomenon has been repeatedly reported in the literature, especially in individuals with bvFTD carrying the C9orf72 expansion. The relevance of this finding for the scope of the discussion presented here is particularly important, given that this etiologic subtype of FTD has consistently been associated with psychotic presentations ${ }^{43}$.

\section{CONCLUSIONS}

The available evidence discussed herein demonstrates how fragile the current understanding is regarding the association between FTD and prior SMI. The issue of misdiagnosis between these conditions is strongly emphasized in many reports.

Dementia superimposed on a severe psychiatric clinical picture, where cognitive impairment and cerebral atrophy arise early from neurodevelopment issues, is a plausible outcome, particularly when considering cognitive and brain reserve contemporary concepts. The underlying neuropathology remains unknown though. However, cases like those described by Dols et al. ${ }^{71}$ and by Gambogi et al. ${ }^{72}$ could not be explained from this perspective. This group of patients deserves a different evaluation workup. If dementia ensues, prognostic predictions and therapeutic choices might be revised. Special attention should be paid to late onset, atypical phenotypes, and to those patients with an unfavorable evolution. In these patients, we suggest the development of investigative algorithms comprising neuropsychological assessment, multimodal neuroimaging, genetic tests, and other biomarkers, including CSF analysis and, perhaps, peripheral inflammatory biomarkers. There is an urgent need 
to reframe the clinical point of view that seems permissive toward progressive or severe cognitive and functional decline in supposed primary psychiatric conditions.

\section{Acknowledgments}

Leonardo Cruz de Souza and Paulo Caramelli are funded by CNPq, Brazil (bolsa de produtividade em pesquisa).

\section{References}

1. Wahlbeck K, Westman J, Nordentoft M, Gissler M, Laursen TM. Outcomes of Nordic mental health systems: life expectancy of patients with mental disorders. Br J Psychiatry. 2011 Dec;199(6):453-8. https://doi.org/10.1192/bjp.bp.110.085100

2. Takada LT. The Genetics of Monogenic Frontotemporal Dementia. Dement Neuropsychol. 2015 Jul-Sep;9(3):219-29. https://doi.org/10.1590/1980-57642015dn93000003

3. Schinnar AP, Rothbard AB, Kanter R, Jung YS. An empirical literature review of definitions of severe and persistent mental illness. Am J Psychiatry. 1990 Dec;147(12):1602-8. https://doi.org/10.1176/ajp.147.12.1602

4. Clementz BA, Sweeney JA, Hamm JP, Ivleva El, Ethridge LE, Pearlson GD, et al. Identification of Distinct Psychosis Biotypes Using Brain-Based Biomarkers. Am J Psychiatry. 2016 Apr;173(4):373-84. https://doi.org/10.1176/appi.ajp.2015.14091200

5. Ivleva EI, Clementz BA, Dutcher AM, Arnold SJ, Jeon-Slaughter $\mathrm{H}$, Aslan S, et al. Brain Structure Biomarkers in the Psychosis Biotypes: Findings From the Bipolar-Schizophrenia Network for Intermediate Phenotypes. Biol Psychiatry. $2017 \mathrm{Jul} ; 82(1): 26-39$. https://doi.org/10.1016/j.biopsych.2016.08.030

6. Velakoulis D, Walterfang M, Mocellin R, Pantelis C, McLean C. Frontotemporal dementia presenting as schizophrenialike psychosis in young people: clinicopathological series and review of cases. Br J Psychiatry. 2009 Apr;194(4):298-305. https://doi.org/10.1192/bjp.bp.108.057034

7. Woolley JD, Khan BK, Murthy NK, Miller BL, Rankin KP. The diagnostic challenge of psychiatric symptoms in neurodegenerative disease: rates of and risk factors for prior psychiatric diagnosis in patients with early neurodegenerative disease. J Clin Psychiatry. 2011 Feb;72(2):126-33. https://doi.org/10.4088/JCP.10m06382oli

8. Rascovsky K, Hodges JR, Knopman D, Mendez MF, Kramer JH, Neuhaus $J$, et al. Sensitivity of revised diagnostic criteria for the behavioural variant of frontotemporal dementia. Brain. 2011 Sep;134(Pt 9):2456-77. https://doi.org/10.1093/brain/awr179

9. Vijverberg EG, Gossink F, Krudop W, Sikkes S, Kerssens C, Prins N, et al. The Diagnostic Challenge of the Late-Onset Frontal Lobe Syndrome: Clinical Predictors for Primary Psychiatric Disorders Versus Behavioral Variant Frontotemporal Dementia.J Clin Psychiatry. 2017 Nov/Dec;78(9):e1197-203. https://doi.org/10.4088/JCP.16m11078

10. Gorno-Tempini ML, Hillis AE, Weintraub S, Kertesz A, Mendez M, Cappa SF, et al. Classification of primary progressive aphasia and its variants. Neurology. 2011 Mar;76(11):1006-14. https://doi.org/10.1212/WNL.0b013e31821103e6

11. Benussi A, Padovani A, Borroni B. Phenotypic Heterogeneity of Monogenic Frontotemporal Dementia. Front Aging Neurosci. 2015 Sep;7:171. https://doi.org/10.3389/fnagi.2015.00171 PMID:26388768

12. Schroeter ML, Raczka K, Neumann J, von Cramon DY. Neural networks in frontotemporal dementia-a metaanalysis. Neurobiol Aging. 2008 Mar;29(3):418-26. https://doi.org/10.1016/j.neurobiolaging.2006.10.023

13. Zhou J, Seeley WW. Network dysfunction in Alzheimer's disease and frontotemporal dementia: implications for psychiatry. Biol Psychiatry. 2014 Apr;75(7):565-73. https://doi.org/10.1016/j.biopsych.2014.01.020

14. Strakowski SM, Adler CM, Almeida J, Altshuler LL, Blumberg HP, Chang KD, et al. The functional neuroanatomy of bipolar disorder: a consensus model. Bipolar Disord. 2012 Jun;14(4):313-25. https://doi.org/10.1111/j.1399-5618.2012.01022.x

15. Watson A, Pribadi M, Chowdari K, Clifton S, Joel Wood, Miller BL, et al. C9orf72 repeat expansions that cause frontotemporal dementia are detectable among patients with psychosis. Psychiatry Res. 2016 Jan;235:200-2. https://doi.org/10.1016/j.psychres.2015.12.007

16. Xu X, Xie S, Shi X, Lv J, Tang X, Wang X, et al. Hexanucleotide Repeat Expansion in C90RF72 Is Not Detected in the Treatment-Resistant Schizophrenia Patients of Chinese Han. PLoS One. 2015 Dec;10(12):e0145347. https://doi.org/10.1371/journal.pone.0145347

17. Boutoleau-Bretonnière C, Evrard C, Hardouin JB, Rocher L, Charriau T, Etcharry-Bouyx F, et al. DAPHNE: A New Tool for the Assessment of the Behavioral Variant of Frontotemporal Dementia. Dement Geriatr Cogn Disord Extra. 2015 Dec;5(3):503-16. https://doi.org/10.1159/000440859

18. Yoshino Y, Mori Y, Ochi S, Numata S, Ishimaru T, Yamazaki K, et al. No abnormal hexanucleotide repeat expansion of C9ORF72 in Japanese schizophrenia patients. J Neural Transm (Vienna). 2015 May;122(5):731-2. https://doi.org/10.1007/s00702-014-1295-y

19. Floris G, Di Stefano F, Pisanu C, Chillotti C, Murru MR, Congiu D, et al. C90RF72 repeat expansion and bipolar disorder - is there a link? No mutation detected in a Sardinian cohort of patients with bipolar disorder. Bipolar Disord. 2014 Sep;16(6):667-8. https://doi.org/10.1111/bdi.12210

20. Galimberti D, Reif A, Dell'osso B, Kittel-Schneider S, Leonhard C, Herr A, et al. C9ORF72 hexanucleotide repeat expansion is a rare cause of schizophrenia. Neurobiol Aging. 2014;35(5):1214 e7-10. https://doi.org/10.1016/j.neurobiolaging.2013.12.004

21. Nicolas G, Beherec L, Hannequin D, Opolczynski G, Rothärmel $\mathrm{M}$, Wallon $\mathrm{D}$, et al. Dementia in middle-aged patients with schizophrenia. J Alzheimers Dis. 2014;39(4):809-22. https://doi.org/10.3233/JAD-131688

22. Huey ED, Nagy PL, Rodriguez-Murillo L, Manoochehri M, Goldman J, Lieberman J, et al. C9ORF72 repeat expansions not detected in a group of patients with schizophrenia. Neurobiol Aging. 2013;34(4):1309 e9-10. https://doi.org/10.1016/j.neurobiolaging.2012.08.011

23. Meisler MH, Grant AE, Jones JM, Lenk GM, He F, Todd PK, et al. C9ORF72 expansion in a family with bipolar disorder. Bipolar Disord. 2013 May;15(3):326-32. https://doi.org/10.1111/bdi.12063

24. de Vries PJ, Honer WG, Kemp PM, McKenna PJ. Dementia as a complication of schizophrenia.J Neurol Neurosurg Psychiatry. 2001 May;70(5):588-96. https://doi.org/10.1136/jnnp.70.5.588

25. Fahey C, Byrne S, McLaughlin R, Kenna K, Shatunov A, Donohoe $G$, et al. Analysis of the hexanucleotide repeat expansion and founder haplotype at C9ORF72 in an Irish psychosis case-control sample. Neurobiol Aging. 2014;35(6):1510 e1-5. https://doi.org/10.1016/j.neurobiolaging.2013.12.003

26. Bosia M, Buonocore M, Guglielmino C, Pirovano A, Lorenzi C, Marcone A, et al. Saitohin polymorphism and executive dysfunction in schizophrenia. Neurol Sci. 2012;33(5):1051-6. https://doi.org/10.1007/s10072-011-0893-9

27. Evin G, Smith MJ, Tziotis A, McLean C, Canterford L, Sharples RA, et al. Alternative transcripts of presenilin-1 associated with frontotemporal dementia. Neuroreport. 2002 May;13(6):917-21. https://doi.org/10.1097/00001756-200205070-00036 
28. Rubino E, Vacca A, Gallone S, Govone F, Zucca M, Gai A, et al. Late onset bipolar disorder and frontotemporal dementia with mutation in progranulin gene: a case report. Amyotroph Lateral Scler Frontotemporal Degener. 2017 Nov;18(7-8):624-6. https://doi.org/10.1080/21678421.2017.1339716

29. Watanabe R, Kawakami I, Onaya M, Higashi S, Arai N, Akiyama $\mathrm{H}$, et al. Frontotemporal dementia with transactivation response DNA-binding protein 43 presenting with catatonic syndrome. Neuropathology. 2018 Jun;38(3):281-287. https://doi.org/10.1111/neup.12442

30. Gramaglia C, Cantello R, Terazzi E, Carecchio M, D’Alfonso S, Chieppa N, et al. Early onset frontotemporal dementia with psychiatric presentation due to the C9ORF72 hexanucleotide repeat expansion: a case report. BMC Neurol. 2014 Nov;14(1):228. https://doi.org/10.1186/s12883-014-0228-6

31. Holm AC. Neurodegenerative and psychiatric overlap in frontotemporal lobar degeneration: a case of familial frontotemporal dementia presenting with catatonia. Int Psychogeriatr. 2014 Feb;26(2):345-7. https://doi.org/10.1017/S1041610213001403

32. Floris G, Borghero G, Cannas A, Stefano FD, Murru MR, Corongiu $D$, et al. Bipolar affective disorder preceding frontotemporal dementia in a patient with C9ORF72 mutation: is there a genetic link between these two disorders? J Neurol. 2013 Apr;260(4):1155-7. https://doi.org/10.1007/s00415-013-6833-2

33. Gourzis P, Skokou M, Polychronopoulos P, Soubasi E, Triantaphyllidou IE, Aravidis C, et al. Frontotemporal dementia, manifested as schizophrenia, with decreased heterochromatin on chromosome 1. Case Rep Psychiatry. 2012;2012:937518. https://doi.org/10.1155/2012/937518

34. Khan BK, Woolley JD, Chao S, See T, Karydas AM, Miller $\mathrm{BL}$, et al. Schizophrenia or neurodegenerative disease prodrome? Outcome of a first psychotic episode in a 35-year-old woman. Psychosomatics. 2012 May-Jun;53(3):280-4. https://doi.org/10.1016/j.psym.2011.04.005

35. Cerami C, Marcone A, Galimberti D, Villa C, Scarpini E, Cappa SF. From genotype to phenotype: two cases of genetic frontotemporal lobar degeneration with premorbid bipolar disorder. J Alzheimers Dis. 2011;27(4):791-7. https://doi.org/10.3233/JAD-2011-110788

36. Momeni P, DeTucci K, Straub RE, Weinberger DR, Davies P, Grafman $J$, et al. Progranulin (GRN) in two siblings of a Latino family and in other patients with schizophrenia. Neurocase. 2010 Jun;16(3):273-9. https://doi.org/10.1080/13554790903456209

37. Momeni P, Wickremaratchi MM, Bell J, Arnold R, Beer R, Hardy $\mathrm{J}$, et al. Familial early onset frontotemporal dementia caused by a novel S356T MAPT mutation, initially diagnosed as schizophrenia. Clin Neurol Neurosurg. 2010 Dec;112(10):917-20. https://doi.org/10.1016/j.clineuro.2010.07.015

38. Stone J, Griffiths TD, Rastogi S, Perry RH, Cleland PG. NonPicks frontotemporal dementia imitating schizophrenia in a 22-year-old man. J Neurol. 2003 Mar;250(3):369-70. https://doi.org/10.1007/s00415-003-0989-0

39. Waddington JL, Youssef HA, Farrell MA, Toland J. Initial 'schizophrenia-like' psychosis in Pick's disease: case study with neuroimaging and neuropathology, and implications for frontotemporal dysfunction in schizophrenia. Schizophr Res. 1995 Dec;18(1):79-82. https://doi.org/10.1016/0920-9964(95)00064-X

40. man.J Neurol. 2003 Mar;250(3):369-70. https://doi.org/10.1007/s00415-003-0989-0

41. Baez S, Pinasco C, Roca M, Ferrari J, Couto B, Garcia-Cordero I, et al. Brain structural correlates of executive and social cognition profiles in behavioral variant frontotemporal dementia and elderly bipolar disorder. Neuropsychologia. 2019 Mar;126:159-69.

42. Metin SZ, Erguzel TT, Ertan G, Salcini C, Kocarslan B, Cebi M, et al. The use of quantitative EEG for differentiating frontotemporal dementia from late-onset bipolar disorder. Clin EEG Neurosci. 2018 May;49(3):171-6. https://doi.org/10.1177/1550059417750914
43. Vijverberg EG, Schouws S, Meesters PD, Verwijk E, Comijs H, Koene T, et al. Cognitive Deficits in Patients With Neuropsychiatric Symptoms: A Comparative Study Between Behavioral Variant Frontotemporal Dementia and Primary Psychiatric Disorders.J Clin Psychiatry. 2017 Sep/Oct;78(8):e940-6. https://doi.org/10.4088/JCP.16m11019

44. Devenney EM, Landin-Romero R, Irish M, Hornberger M, Mioshi E, Halliday GM, et al. The neural correlates and clinical characteristics of psychosis in the frontotemporal dementia continuum and the C9orf72expansion. Neuroimage Clin. 2016 Dec;13:439-45. https://doi.org/10.1016/j.nicl.2016.11.028

45. Chan HM, Stolwyk R, Neath J, Kelso W, Walterfang M, Mocellin $\mathrm{R}$, et al. Neurocognitive similarities between severe chronic schizophrenia and behavioural variant frontotemporal dementia. Psychiatry Res. 2015 Feb;225(3):658-66. https://doi.org/10.1016/j.psychres.2014.11.029

46. Chan HM, Stolwyk R, Kelso W, Neath J, Walterfang M, Mocellin $\mathrm{R}$, et al. Comparing neurocognition in severe chronic schizophrenia and frontotemporal dementia. Aust N ZJ Psychiatry. 2014 Sep;48(9):828-37. https://doi.org/10.1177/0004867414529477

47. Nishida K, Morishima Y, Yoshimura M, Isotani T, Irisawa S, Jann $\mathrm{K}$, et al. EEG microstates associated with salience and frontoparietal networks in frontotemporal dementia, schizophrenia and Alzheimer's disease. Clin Neurophysiol. 2013 Jun;124(6):1106-14. https://doi.org/10.1016/j.clinph.2013.01.005

48. Weickert TW, Leslie F, Rushby JA, Hodges JR, Hornberger M. Probabilistic association learning in frontotemporal dementia and schizophrenia. Cortex. 2013 Jan;49(1):101-6. https://doi.org/10.1016/j.cortex.2011.09.011

49. Bediou B, Brunelin J, d'Amato T, Fecteau S, Saoud M, Hénaff $\mathrm{MA}$, et al. A comparison of facial emotion processing in neurological and psychiatric conditions. Front Psychol. 2012 Apr;3:98. https://doi.org/10.3389/fpsyg.2012.00098

50. Ziauddeen H, Dibben C, Kipps C, Hodges JR, McKenna PJ. Negative schizophrenic symptoms and the frontal lobe syndrome: one and the same? Eur Arch Psychiatry Clin Neurosci. 2011 Feb;261(1):59-67. https://doi.org/10.1007/s00406-010-0133-y

51. Schoder D, Hannequin D, Martinaud O, Opolczynski G, Guyant-Maréchal L, Le Ber I, et al. Morbid risk for schizophrenia in first-degree relatives of people with frontotemporal dementia. Br J Psychiatry. 2010 Jul;197(1):28-35. https://doi.org/10.1192/bjp.bp.109.068981

52. Foley J, Golden C, Simco E, Schneider B, McCue R, Shaw L. Corollary-and discrepancy-based approaches for examining the appropriateness of premorbid cognitive estimation in geriatric schizophrenia. Int J Neurosci. 2009;119(10):1810-29. https://doi.org/10.1080/00207450903192878

53. Velakoulis D, Walterfang M, Mocellin R, Pantelis C, Dean B, McLean C. Abnormal hippocampal distribution of TDP-43 in patients withlate onset psychosis. Aust N Z J Psychiatry. 2009 Aug;43(8):739-45. https://doi.org/10.1080/00048670903001984

54. Foley J, Golden C, Simco E, Schneider B, McCue R, Shaw L. Pattern of memory compromise in chronic geriatric schizophrenia, frontotemporal dementia and normal geriatric controls. Acta Neuropsychiatr. 2008 Feb;20(1):9-19. https://doi.org/10.1111/j.1601-5215.2007.00244.x

55. Kosmidis MH, Aretouli E, Bozikas VP, Giannakou M, loannidis P. Studying social cognition in patients with schizophrenia and patients with frontotemporal dementia: theory of mind and the perception of sarcasm. Behav Neurol. 2008;19(1-2):65-9. https://doi.org/10.1155/2008/157356

56. American Psychiatric Association. Diagnostic and statistical manual of mental disorders. 5th ed. Arlington (VA): American Psychiatric Association; 2013.

57. Gambogi LB, Guimarães HC, Daker MV, de Souza LC, Caramelli P. Kraepelin's description of chronic mania: a clinical picture that meets the behavioral variant frontotemporal dementia phenotype. Arq Neuropsiquiatr. 2016 Sep;74(9):775-7. https://doi.org/10.1590/0004-282X20160111 
58. Mollon J, David AS, Zammit S, Lewis G, Reichenberg A. Course of Cognitive Development From Infancy to Early Adulthood in the Psychosis Spectrum. JAMA Psychiatry. 2018 Mar;75(3):270-9. https://doi.org/10.1001/jamapsychiatry.2017.4327

59. Hill SK, Reilly JL, Keefe RS, Gold JM, Bishop JR, Gershon ES, et al. Neuropsychological impairments in schizophrenia and psychotic bipolar disorder: findings from the BipolarSchizophrenia Network on Intermediate Phenotypes (B-SNIP) study. Am J Psychiatry. 2013 Nov;170(11):1275-84. https://doi.org/10.1176/appi.ajp.2013.12101298

60. Menezes NM, Arenovich T, Zipursky RB. A systematic review of longitudinal outcome studies of first-episode psychosis. Psychol Med. 2006 Oct;36(10):1349-62. https://doi.org/10.1017/S0033291706007951

61. Martínez-Arán A, Vieta E, Reinares M, Colom F, Torrent C, SánchezMoreno J, et al. Cognitive function across manic or hypomanic, depressed, and euthymic states in bipolar disorder. Am J Psychiatry. 2004 Feb;161(2):262-70. https://doi.org/10.1176/appi.ajp.161.2.262

62. Gossink FT, Dols A, Krudop WA, Sikkes SA, Kerssens CJ, Prins ND, et al. Formal Psychiatric Disorders are not Overrepresented in Behavioral Variant Frontotemporal Dementia. J Alzheimers Dis. 2016;51(4):1249-56. https://doi.org/10.3233/JAD-151198

63. Shinagawa S, Nakajima S, Plitman E, Graff-Guerrero A, Mimura M, Nakayama K, et al. Psychosis in frontotemporal dementia.J Alzheimers Dis. 2014;42(2):485-99. https://doi.org/10.3233/JAD-140312

64. Vijverberg EG, Dols A, Krudop WA, Del Campo Milan M, Kerssens CJ, Gossink F, et al. Cerebrospinal fluid biomarker examination as a tool to discriminate behavioral variant frontotemporal dementia from primary psychiatric disorders. Alzheimers Dement (Amst). 2017 Mar;7:99-106. https://doi.org/10.1016/j.dadm.2017.01.009

65. Krudop WA, Dols A, Kerssens CJ, Prins ND, Möller C, Schouws S, et al. Impact of Imaging and Cerebrospinal Fluid Biomarkers on Behavioral Variant Frontotemporal Dementia Diagnosis within a Late-Onset Frontal Lobe Syndrome Cohort. Dement Geriatr Cogn Disord. 2016;41(1-2):16-26. https://doi.org/10.1159/000441023

66. Najjar S, Pearlman DM, Alper K, Najjar A, Devinsky O Neuroinflammation and psychiatric illness. J Neuroinflammation. 2013 Apr;10(1):43. https://doi.org/10.1186/1742-2094-10-43

67. Wyatt RJ. Neuroleptics and the natural course of schizophrenia. Schizophr Bull. 1991;17(2):325-51. https://doi.org/10.1093/schbul/17.2.325

68. Bangalore SS, Goradia DD, Nutche J, Diwadkar VA, Prasad KM, Keshavan MS. Untreated illness duration correlates with gray matter loss in first-episode psychoses. Neuroreport. 2009 May;20(7):729-34. https://doi.org/10.1097/WNR.0b013e32832ae501

69. Zipursky RB, Reilly TJ, Murray RM. The myth of schizophrenia as a progressive brain disease. Schizophr Bull. 2013 Nov;39(6):1363-72. https://doi.org/10.1093/schbul/sbs135
70. Post RM. Transduction of psychosocial stress into the neurobiology of recurrent affective disorder. Am J Psychiatry. 1992 Aug;149(8):999-1010. https://doi.org/10.1176/ajp.149.8.999

71. Kapczinski F, Vieta E, Andreazza AC, Frey BN, Gomes FA, Tramontina J, et al. Allostatic load in bipolar disorder: implications for pathophysiology and treatment. Neurosci Biobehav Rev. 2008;32(4):675-92. https://doi.org/10.1016/j.neubiorev.2007.10.005

72. Dols A, Krudop W, Möller C, Shulman K, Sajatovic M, Pijnenburg YA. Late life bipolar disorder evolving into frontotemporal dementia mimic. Neuropsychiatr Dis Treat. 2016 Sep;12:2207-12. https://doi.org/10.2147/NDT.S99229

73. Gambogi LB, Guimarães HC, de Souza LC, Caramelli P. LongTerm Severe Mental Disorders Preceding Behavioral Variant Frontotemporal Dementia: Frequency and Clinical Correlates in an Outpatient Sample. J Alzheimers Dis. 2018;66(4):1577-85. https://doi.org/10.3233/JAD-180528

74. Lisy ME, Jarvis KB, DelBello MP, Mills NP, Weber WA, Fleck $D$, et al. Progressive neurostructural changes in adolescent and adult patients with bipolar disorder. Bipolar Disord. 2011 Jun;13(4):396-405. https://doi.org/10.1111/j.1399-5618.2011.00927.x

75. Hallahan B, Newell J, Soares JC, Brambilla P, Strakowski SM, Fleck DE, et al. Structural magnetic resonance imaging in bipolar disorder: an international collaborative mega-analysis of individual adult patient data. Biol Psychiatry. 2011 Feb;69(4):326-35. https://doi.org/10.1016/j.biopsych.2010.08.029

76. Strakowski SM, DelBello MP, Zimmerman ME, Getz GE, Mills NP, Ret J, et al. Ventricular and periventricular structural volumes in first-versus multiple-episode bipolar disorder. Am J Psychiatry. 2002 Nov;159(11):1841-7. https://doi.org/10.1176/appi.ajp.159.11.1841

77. Lampron A, Elali A, Rivest S. Innate immunity in the CNS: redefining the relationship between the CNS and Its environment. Neuron. 2013 Apr;78(2):214-32. https://doi.org/10.1016/j.neuron.2013.04.005

78. Cagnin A, Brooks DJ, Kennedy AM, Gunn RN, Myers R, Turkheimer FE, et al. In-vivo measurement of activated microglia in dementia. Lancet. 2001 Aug;358(9280):461-7. https://doi.org/10.1016/S0140-6736(01)05625-2

79. Tate JA, Snitz BE, Alvarez KA, Nahin RL, Weissfeld LA, Lopez O, et al.; GEM Study Investigators. Infection hospitalization increases risk of dementia in the elderly. Crit Care Med. 2014 May;42(5):1037-46. https://doi.org/10.1097/CCM.0000000000000123

80. Whitwell JL, Josephs KA, Avula R, Tosakulwong N, Weigand SD, Senjem ML, et al. Altered functional connectivity in asymptomatic MAPT subjects: a comparison to bvFTD. Neurology. 2011 Aug;77(9):866-74. https://doi.org/10.1212/WNL.0b013e31822c61f2

81. Mclntosh AM, Muñoz Maniega S, Lymer GK, McKirdy J, Hall J, Sussmann JE, et al. White matter tractography in bipolar disorder and schizophrenia. Biol Psychiatry. 2008 Dec;64(12):1088-92. https://doi.org/10.1016/j.biopsych.2008.07.026 